\title{
Disonansi Kognitif Wanita Pekerja Seks Komersial yang Bekerja Menghidupi Keluarga
}

\author{
Indra Prastyo ${ }^{1}$, Suryanto ${ }^{2}$, Amanda Pasca Rini ${ }^{3}$ \\ Program Studi Magister Sains Psikologi Universitas 17 Agustus 1945 Surabaya $^{1}$ \\ Email: indra_s2@untag-sby.ac.id ${ }^{1,}$ suryanto@psikologi.unair.ac.id ${ }^{2}$, \\ Amanda@untag-sby.ac.id ${ }^{3}$
}

\begin{abstract}
Abstrak
Teori disonansi kognitif merupakan sebuah teori dalam psikologi sosial yang membahas mengenai perasaan ketidak nyamanan seseorang akibat sikap, pemikiran dan perilaku yang saling bertentangan dan memotivasi seseorang untuk mengambil langkah demi mengurangi ketidaknyamanan tersebut. Dalam menganalisis Disonansi Kognitif yang dialami PSK peneliti menggunakan Teori CDT (Cognitive Dissonance Theory) dari Bescheid \& Walster untuk mengungkap disonansi kognitif PSK. Tujuan dari penelitian ini adalah menganalisis faktor-faktor utama yang membentuk disonansi kognitif pada pekerja seks komersial yang tetap melakukan pekerjaan tersebut demi mencukupi kebutuhan keluarganya di wilayah makam kembang kuning Surabaya. Penelitian ini menggunakan metode deskriptif kualitatif dengan pendekatan fenomenologi transendental. Pemilihan sampel yang digunakan adalah purposive sampling dalam memilih subjek sebagai informan dengan pertimbangan bahwa subjek adalah pelaku yang dianggap mengerti permasalahan yang terjadi. Teknik pengumpulan data adalah dengan wawancara mendalam, studi dokumentasi dan observasi. Hasil penelitian menunjukan, terdapat banyak pertentangan dalam diri PSK sehingga menyebabkan disonansi kognitif dialami oleh PSK, Faktor yang paling kuat membuat PSK merasa disonan adalah faktor keluarga, dan juga cemoohan serta perkucilan oleh masyarakat. Konsonan dalam diri PSK beranggapan bahwa pekerjaan sebagai PSK menjadi sebuah pekerjaan yang mudah tanpa keahlian khusus dengan hasil yang menurut beberapa PSK memuaskan, PSK dapat terus berpenampilan cantik dan menarik, sementara disonan PSK adalah memilih bekerja sebagai PSK padahal mengetahui itu salah, dosa, dan merugikan orang lain termasuk merusak rumah tangga orang. Penelitian ini bisa membantu mengurangi PSK, karena dalam penelitian ini ada beberapa hal yang menjelaskan mengapa wanita tetap menjadi PSK dan dengan mengetahui alasan diharapkan bisa menekan jumlah PSK. Saran bagi peneliti selanjutnya dapat meneliti tentang konsep diri PSK, karena dalam penelitian ini terdapat temuan mengenai konsep diri PSK yang diwarnai oleh konsep diri semu karena sifat suka berbohong untuk menutupi aibnya dengan memakai topeng dalam bentuk topeng sosial dan topeng moral.
\end{abstract}

Kata kunci : Disonansi Kognitif, Pekerja Seks Komersial

Dipresentasikan dalam Seminar Nasional "Membangun Resiliensi di Era Revolusi Industri 4.0" Fakultas Psikologi Unissula, 22 September 2019 


\section{Pendahuluan}

Manusia sebagai makhluk sosial tidak akan lepas dari banyak masalah sosial, salah satu masalah sosial tersebut adalah masalah pelacuran. Definisi pelacuran sendiri merupakan suatu bentuk transaksi bisnis yang disepakati oleh pihak yang terlibat sebagai suatu yang bersifat jangka pendek yang memungkinkan satu orang atau lebih mendapatkan kepuasan seks dengan metode yang beraneka ragam (Perkins \& Bannet dalam Koentjoro 2004:29).

Fenomena pelacuran atau sering disebut sebagai PSK (Pekerja Seks Komersial) ditengarai telah ada sejak lama seiring dengan peradaban manusia. Keberadaannya seringkali menimbulkan situasi dilematis. PSK itu sendiri mengandung makna suatu perbuatan yang dilakukan oleh wanita dengan menawarkan serta menjual seks kepada kaum lelaki untuk melakukan hubungan seksual yang mana akan memperoleh sejumlah bayaran sebagai imbalan pemenuhan kepuasan biologis yang telah diberikan. Banyak kekhawatiran yang timbul akibat adanya PSK ini, sebab tidak hanya membuat keresahan di tengah-tengah masyarakat, maupun penyebab degradasi moral, melainkan juga kekhawatiran akan semakin menjalarnya penyakit akibat hubungan seks yang menyimpang (Munawaroh, 2010).

Seperti dilansir dari Nasional Kompas.com (13/6/2018), fenomena keberadaan makam kembang kuning Surabaya sebagai tempat lokalisasi terselubung bukanlah hal baru, semenjak lokalisasi Dolly resmi ditutup oleh pemerintah pada Tahun 2013 hal tersebut tidak menutup peluang para PSK tersebut menjajakan dirinya, salah satu tempat yang sering dijadikan mangkal oleh PSK tersebut untuk mencari lelaki hidung belang adalah wilayah komplek pemakaman kembang kuning Surabaya

(https://nasional.kompas.com/read/2008/06/14/13261337/pujasera.seks.berna ma.makam.kembang.kuning?page=all).

Sebelum terjun kedalam bisnis pelacuran, para wanita pekerja seks komersial pasti memiliki beragam alasan, Penelitian dari Christie dan Purwandari (2008) menunjukkan ada empat hal yang melatarbelakangi orang jadi PSK yaitu terdesak 
kebutuhan ekonomi, latar belakang pendidikan yang rendah, sakit hati dengan kehidupan masa lalu dan adanya pihak ketiga yang menawarkan solusi.

Berdasarkan uraian di atas, penulis ingin menganalisis faktor-faktor utama yang membentuk disonansi kognitif para pekerja seks komersial yang tetap melakukan pekerjaan tersebut demi mencukupi kebutuhan keluarganya di wilayah makam kembang kuning Surabaya.

Menurut Festinger (dalam Sofiana, 2013) disonansi kognitif adalah ketidak sesuaian yang terjadi antara dua elemen kognitif yang tidak konsisten yang menyebabkan ketidak nyamanan psikologis serta mendorong seseorang untuk berbuat sesuatu agar disonansi itu dapat dikurangi.

Menurut Bescheid \& Walster (dalam Munawaroh, 2010) teori CDT (Cognitive Dissonance Theory) berkaitan dengan proses pemilihan terpaan (selective exposure), pemilihan perhatian (selective attention), pemilihan interpretasi (selective interpretation), dan pemilihan retensi (selective retention) karena teori ini memprediksi bahwa orang akan menghindari informasi yang meningkatkan disonansi.

\section{Metode}

a. Desain penelitian.

Penelitian ini menggunakan metode penelitian kualitatif deskriptif dengan pendekatan fenomenologi transendental. Memilih metode kualitatif karena peneliti memiliki tujuan untuk mendapatkan data dan menganalisisnya secara mendalam, detail, dan akurat. Jadi, lingkup kedalaman data lebih dipentingkan dari pada aspek keluasan data.

b. Partisipan.

Partisipan dalam penelitian ini adalah PSK di wilayah makam kembang kuning Surabaya. Penelitian ini tidak mementingkan besarnya populasi atau sampling, bahkan populasi atau samplingnya sangat terbatas. Teknik pengumpulan data adalah dengan wawancara mendalam, studi dokumentasi, dan observasi. Peneliti dalam penelitian ini menggunakan teknik purposive sampling dalam memilih subjek 
informan dengan pertimbangan bahwa subjek adalah pelaku yang dianggap mengerti permasalahan yang terjadi.

Adapun kriteria subjek yang akan dijadikan sebagai informan adalah: Perempuan yang bekerja sebagai PSK dan bersedia memberikan keterangan atau informasi yang dibutuhkan untuk menjawab pertanyaan penelitian ini dengan jujur, dan seorang yang terbuka. Penelitian ini membahas tentang disonansi kognitif pada Wanita yang bekerja sebagai PSK untuk menghidupi keluarga yang merupakan masalah pribadi dalam diri mereka.

c. Prosedur.

Penelitian ini menggunakan pendekatan fenomenologi karena dengan metode fenomenologi lebih bisa mengungkapkan dan menjelaskan pengalaman yang dialami oleh objek penelitian untuk diolah daripada menggunakan metode lain. Hal ini sesuai dengan pendapat kuswano yaitu fenomenologi mempelajari fenomena yang tampak di depan kita, dan bagaimana penampakannya (Kuswarno, 2009:3). Prosedur penelitian yang dilakukan oleh peneliti adalah didasarkan pada tahapan dalam proses penelitian kualiatatif oleh Neuman (2017) yaitu: menentukan tema penelitian, menentukan pertanyaan penelitian, merancang penelitian, mengumpulkan data, menganalsis data, menginterpretasi data, membuat laporan penelitian.

d. Teknik analisis.

Unit analisis data adalah kajian penelitian yang dikelompokkan dalam unit-unit tertentu. Unit data yang akan dianalisis pada penelitian ini adalah pernyataan yang dikemukakan oleh subjek penelitian. Pernyataan yang dikeluarkan langsung dari subjek penelitian tanpa adanya perantara. Data tersebut berupa data asli yang di dapat dari para informan.

Pada penelitian ini, unit analisis datanya adalah pernyataan hasil penelitian melalui wawancara mendalam dengan subjek penelitian, meliputi semua jawaban tentang disonansi kognitif wanita pekerja seks komersial yang bekerja menghidupi keluarga, dan terakhir menyajikan data dalam bentuk pembahasan (Creswell, 2015). 


\section{Hasil}

Setiap wanita pada dasarnya tidak ada yang benar benar menginginkan menjadi PSK, namun dalam kenyataannya banyak sekali wanita yang menjadi seorang pekerja seks komersial (Munawaroh, 2010). Dalam pengambilan keputusan menjadi pekerja seks komersial ini pasti memunculkan pertentangan pertentangan dalam diri wanita bersangkutan. Pertentangan dalam diri ini bisa juga disebut disonansi kognitif. Disonansi Kognitif merupakan perasaan yang dimiliki orang ketika mereka menemukan diri mereka sendiri melakukan sesuatu yang tidak sesuai dengan apa yang mereka ketahui, atau mempunyai pendapat yang tidak sesuai dengan pendapat lain yang mereka pegang (Japarianto, 2006).

Masing-masing individu memiliki alasan tersendiri dan mengalami pertentangan dalam diri yang berbeda-beda. Banyak wanita yang menjadi PSK mengalami disonansi tidak hanya dengan diri sendiri tetapi juga berkaitan dengan keluaraga dan lingkungan. Mengambil keputusan untuk menjadi PSK bukan hal mudah bagi para wanita ini karena dalam prosesnya mereka harus benar benar bergulat dengan pikiran dan nuraninya. Pengambilan keputusan sangat dipengaruhi oleh latar belakang keluarga yang turut andil dalam pembentukan kepribadian dan pemahaman akan nilai dan norma yang tertanam dalam diri setiap orang.

Sebagaimana pernyataan yang disebutkan dalam disonansi kognitif dalam diri sebelum menjadi PSK bahwa setiap wanita akan mengalami disonansi dalam mengambil keputusan menjadi PSK. Ada yang merasa berat untuk menjadi PSK karena takut tertular penyakit, takut ketahuan saudara atau teman dari kampung, ada karena takut anaknya nanti mengetahui pekerjaan Ibunya. Para PSK ini sebagian besar tidak memberitahukan profesi mereka kepada keluarganya ataupun temanteman dikampungnya. Walaupun ada satu atau dua orang PSK yang sangat terbuka kepada siapapun tentang profesi mereka. Beberapa PSK yang keluarganya mengetahui profesi yang di jalani lebih memilih tidak menanggapi nasehat dari keluarga dan jika mendapat komentar dari salah satu keluarga maka yang dilakukan adalah menjauhi orang tersebut. 
Setiap PSK mengaku ingin berhenti namun tidak untuk saat ini, artinya mereka mau berhenti tapi tidak tahu kapan akan berhenti. Hal ini karena mereka masih menikmati profesi yang di anggap mereka mudah dan satu satunya pekerjaan yang bisa di lakukan.

Sedangkan menurut Festinger (dalam Breckler, Olson, \& Wiggins, 2006) hubungan konsonan (consonant relationship) ada antara dua elemen ketika dua elemen tersebut pada posisi seimbang satu sama lain. Dalam penelitian ini hubungan yang konsonan terjadi ketika PSK yakin bahwa mereka bisa mendapatkan kepuasan dan uang hanya dengan bekerja sebagai pekerja seks maka mereka tidak akan berhenti dari kegiatan tersebut. Lanjut Festinger (dalam Breckler, Olson, \& Wiggins, 2006), hubungan disonansi (dissonant relationship) berarti bahwa elemenelemennya tidak seimbang satu dengan lainnya. Dalam penelitian ini terdapat pada mereka yang merasa bersalah kepada keluarga khususnya pada ayah ibu dan anak berkaitan dengan latar belakang keluarga. Pentingnya disonansi kognitif bagi peneliti ditunjukkan dalam pernyataan Festinger bahwa ketidak nyaman yang disebabkan oleh disonansi akan mendorong terjadinya perubahan. Perubahan yang dilakukan para PSK adalah pada bagaimana mereka memperlakukan keluarga, tetangga, dan teman dengan memberi banyak barang atau makanan untuk mengatasi ketidak nyamanan yang dirasakan selama menjadi PSK. Dalam pemikiran mereka juga terdapat perubahan pola pikir yang awalnya menentang menjadi PSK menjadi mendukung untuk menjadi PSK yang tampak dari bagaimana mereka berpenampilan, memilih tempat tinggal, dan dengan siapa mereka bergaul.

\section{Diskusi}

Faktor-Faktor Yang Mempengaruhi Disonansi Kognitif PSK

Faktor-faktor yang dapat mempengaruhi tingkat disonansi yang dirasakan seseorang menurut Zimbardo, Ebbsen \& Maslach (dalam Annisa, 2013) adalah sebagai berikut: 
1. Kepentingan, atau seberapa signifikan suatu masalah, berpengaruh terhadap tingkat disonansi yang dirasakan. Masalah muncul ketika PSK merasa bersalah pada keluarga, anak dan orang terdekatnya berkaitan dengan profesi mereka sebagai pekerja seks.

2. Rasio disonansi atau jumlah kognisi disonan berbanding dengan jumlah kognisi yang konsonan. Penyebab disonansi bisa muncul dari mana saja termasuk lingkungan sekitar. Jumlah kognisi yang disonan lebih banyak karena keluarga dan lingkungan selalu hadir dan tidak bisa jauh dari kehidupan para informan, selain itu keluarga selalu terhubung dan tidak bisa putus pertaliannya.

3. Rasionalitas yang digunakan individu untuk menjustifikasi inkonsistensi. Faktor ini merujuk pada alasan yang dikemukakan untuk menjelaskan mengapa sebuah inkonsistensi muncul.

Analisis Dasar Penghindaran Disonansi Kognitif PSK

Dalam menganalisis Disonansi Kognitif yang dialami PSK penulis menggunakan Teori CDT (Cognitive Dissonance Theory) menurut Bescheid \& Walster (dalam Munawaroh, 2010) yang berkaitan dengan proses pemilihan terpaan (selective exposure), pemilihan perhatian (selective attention), pemilihan interpretasi (selective interpretation), dan pemilihan retensi (selective retention) karena teori ini memprediksi bahwa orang akan menghindari informasi yang meningkatkan disonansi.

1. Terpaan Selektif (Selective Exposure)

Mencari informasi yang konsisten yang belum ada, membantu untuk mengurangi disonansi. CDT (Cognitive Dissonance Theory) memprediksikan bahwa orang akan menghindari informasi yang meningkatkan disonansi dan mencari informasi yang konsisten dengan sikap dan perilaku mereka

\section{Pemilihan Perhatian (SelectiveAttention)}

Merujuk pada melihat informasi secara konsisten begitukonsisten itu ada. Orang memperhatikan informasi dalam lingkungannya yang sesuai dengan sikap dan keyakinannya sementara tidak menghiraukan informasi yang tidak konsisten. 


\section{Interpretasi Selektif (Selective Interpretation)}

Melibatkan penginterpretasian informasi yang ambigu sehingga menjadi konsisten. Dengan menggunakan interpretasi selektif, kebanyakan orang menginterpretasikan sikap teman dekatnya sesuai dengan sikap mereka sendiri dari pada yang sebenarnya terjadi. Retensi Selektif (Selective Retention)

Leon Festinger menyebutkan empat hal yang dilakukan seseorang untuk mengurangi disonansi, empat hal itu adalah mengubah perilaku, mengubah kognisi, Memperkuat salah satu kognisi yang disonan, dan menganggap salah satu kognisi tidak penting.

Para informan akan melakukan hal-hal untuk mengurangi disonansi yang di alami adalah dengan mengubah perilaku yaitu, tertutup pada lingkungan sekitar termasuk pada keluarga, Berpenampilan muslimah dan sopan ketika tidak sedang bekerja (pulang kampung) dan suka memberi barang atau hadiah baik berupa makanan maupun benda pada anggota keluarga dan tetangga sekitar.

Berikutnya dengan mengubah kognisi tentang lingkungan, seperti merasa bahwa menjadi PSK adalah karena terpaksa (faktor ekonomi, ditipu, pelampiasan sakit hati), merasa tidak ada masalah dengan penyakit karena selalu memiliki biaya untuk ke dokter spesialis baik untuk mencegah kehamilan maupun IMS (Infeksi Menular Seksual), selanjutnya adalah memperkuat salah satu kognisi yang disonan dengan mengatakan dan menanamkan dalam dirinya bahwa banyak wanita juga menjadi PSK.

\section{Kesimpulan}

Berdasarkan hasil penelitian, banyak faktor-faktor utama disonan yang mempengaruhi disonansi kognitif yang dialami PSK seperti adalah faktor hukuman sosial yang didapatkan, seperti dikucilkan keluarga, dicemooh, perlakuan dan cap negatif masyarakat yang akan di tempelkan pada diri mereka jika profesi mereka sampai di ketahui masyarakat atau keluarga. Kognisi disonan muncul karena dalam masyarakat umum menganggap profesi yang dijalani oleh para PSK adalah profesi yang dianggap buruk, hina, dan penuh dosa. Para PSK merasa masalah muncul 
ketika PSK merasa bersalah pada keluarga, anak dan orang terdekatnya berkaitan dengan profesi mereka sebagai pekerja seks, mereka akan melakukan hal-hal untuk mengurangi disonansi yang di alami dengan mengubah perilaku yaitu, tertutup pada lingkungan sekitar termasuk pada keluarga, berpenampilan muslimah dan sopan ketika tidak sedang bekerja (pulang kampung) dan suka memberi barang atau hadiah baik berupa makanan maupun benda pada anggota keluarga dan tetangga sekitar.

Sedangkan cara mereka mengurangi Disonansi Kognitif dalam bekerja sebagai PSK, mereka mengubah kognisi tentang lingkungan, seperti merasa bahwa menjadi PSK adalah karena terpaksa (faktor ekonomi, ditipu, pelampiasan saki hati), merasa tidak ada masalah dengan penyakit karena selalu memiliki biaya untuk ke dokter spesialis baik untuk mencegah kehamilan maupun IMS (Infeksi Menular Seksual). Faktor yang paling kuat membuat mereka merasa disonan adalah faktor keluarga dan juga cemoohan serta perkucilan oleh masyarakat, sedangkan cara mereka mengatasi hal tersebut dengan memperkuat salah satu kognisi yang disonan, dan menganggap salah satu kognisi tidak penting. Konsonan dalam diri PSK, mereka beranggapan bahwa pekerjaan sebagai PSK menjadi sebuah pekerjaan yang mudah tanpa keahlian khusus dengan hasil yang menurut mereka memuaskan, mereka dapat terus berpenampilan cantik dan menarik. Sementara disonan mereka adalah mereka memilih bekerja sebagai PSK padahal mereka mengetahui itu salah, dosa, dan merugikan orang lain termasuk merusak rumah tangga orang.

\section{Daftar Pustaka}

Budi Susetyo,\& Y. Sudiantara. 2015. Konsep Diri Pada Pekerja Seks Komersial. Psikodimensia. Vol. 14 / 2.

Baron, R.A \& Byrne.1991.Social Psychology Understanding Human Interaction6 Th.USA : Allyn and Bacon.

Berscheid, E. \&. E. Walster. 1978. Interpersonal Attraction 2nd edition. Addison Wesley Publishing Company 
Creswell, John W. 2015. Penelitian Kualitatif dan Desain Riset. Edisi 3. Pustaka Pelajar, Yogyakarta.

Christie dan Poerwandari, K. 2008. Kebahagiaan Pada Pekerja Seks Komersial Kelas Bawah di Jakarta. Jurnal Psikologi Sosial, Vol. 14. No.03, hal.219-230.

Juwita, Elanda. 2013. Pekerja Seks Komersial yang Berkeluarga. Departemen Sosiologi. Vol 3 No 5.

Koentjoro. 2004. On the Spot: Tutur Sang Pelacur. Yogyakarta, Tinta.

Munawaroh, Siti. 2010. Pekerja Seks Komersial (PSK) di Wilayah Prambanan, Kabupaten Klaten, Jawa Tengah. Dimensia, Volume 4, No. 2.

Rakhmat, J. 2007. Psikologi Komunikasi. Bandung: PT Remaja Rosdakarya.

Sarwono, S.W. 1999. Psikologi Sosial.Individu dan Teori-Teori PsikologiSosial. Jakarta: Penerbit Balai Pustaka.

Sofiana, Mega. 2013. Disonansi Kognitif dalam Pengambilan Keputusan untuk Menjadi Wanita Pekerja Seks.Publicrelation. Vol 2 No 4.

Sugiyono, 2008. metode penelitian kuantitatif kualitatif dan $R \& D$. bandung.

Sweeney, Jillian C., Hauscknecht, Douglas. \& Soutar, Geoffrey N., 2000. Cognitive Dissonance after Purchase: A Multidimensional Scale. Psychology and Marketing, vol.17.

Utami, Mardina. 2011. Managemen Konflik Pada Wanita Pekerja Seks Yang Berkeluarga. Intisari. Jurnal Psikologi : Universitas Diponegoro Semarang.

Ward, C., Bochner, S., \& Furnham, A. 2001. The psychology of culture shock. London: Routledge. 